\title{
La voz inédita: Georg Büchner
}

\author{
ANTONIO MoLINA FloReS \\ Universidad de Sevilla
}

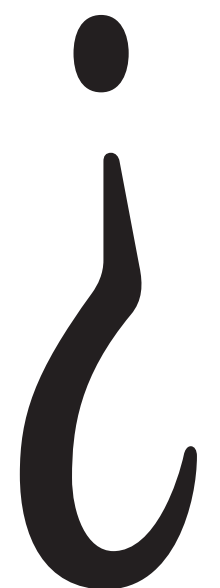

Se puede ser un clásico de la literatura habiendo vivido solo veintitrés años y cinco meses?

Por diversos caminos y en contextos distintos, la literatura del siglo XIX nos dejó a tres autores extraordinarios, unidos por la precocidad: Rimbaud, Lautréamont y Büchner.

Arthur Rimbaud, si bien vivió muchos más años, dejó la literatura a los diecinueve. Solo usará papel para escribir a su familia cartas desde Abisinia, su lugar de huida. Isidoro Duchase, que firmará sus obras como Conde de Lautréamont, tenía veinticuatro años al morir, dejándonos sus Poésies y, sobre todo, sus deslumbrantes Chants de Maldoror.

Georg Büchner es, como Novalis, un joven interesado por las ciencias prácticas, lo que le aporta un método de indagación, experimentación y conocimiento que se aplica después a otros ámbitos, como el arte o la literatura. No se trata de un difuso y laxo "generar conocimiento", sino aportar resultados.

Ajeno, en principio a las tradiciones literarias de su época, aunque con un buen conocimiento de los clásicos, se enfrenta a los problemas sociales, psicológicos y políticos de su tiempo sin mirar al pasado. Pero con una sorprendente eficacia, hace un diagnóstico, expone la situación y muestra las contradicciones con una riqueza de matices que lo mantienen vivo en la distancia de dos siglos. Porque, ¿qué es un clásico sino aquél que sigue dando una respuesta siempre imaginativa y aún válida a problemas que perduran? Esos problemas a los que se enfrenta Büchner en su obra literaria son pocos y están bien identificados: ¿Cómo afectan el poder y los poderes a un individuo concreto? ¿En qué consiste la verdadera revolución? ¿Qué papel debe tener la política en la sociedad?

Podemos aventurar que mientras haya individuos, capacidad de acción y polis, la obra de Büchner permanecerá abier- ta, frondosa y seductora como una extraña flor. Pero también problemática. Porque al no simplificar los elementos conflictivos, lo que aporta es una visión rigurosa, llena de matices y soluciones que no agotan la acción.

No necesitó conocer a Hegel ni a Fichte para aplicar un método plenamente dialéctico, dejando atrás tanto el idealismo como los efluvios románticos. Marx nació cuando Büchner tenía cinco años y éste se le adelantó también al entender la importancia de los factores socio-económicos. Por eso fue autor de cabecera de Franz Kafka o Bertold Brecht.

La literatura es el bisturí con el que diseccionamos a ese enfermo terminal que llamamos sociedad moderna.

Tolstoi, en Guerra y Paz, también mostrará sin concesiones cómo es la sociedad de su tiempo, y las consecuencias de la guerra. Pero, por decirlo suavemente, lo hará desde una posición de clase. Como sombras que desaparecen cita a «siervos», «esclavos», «sirvientes», «ayas». Ninguno de estos -y son muchas sus apariciones, literalmente, como espectrostiene nombre, y mucho menos apellidos. Pero quienes aman, mueren, se divierten, son «príncipes», «princesas», «generales», «emperadores» (hasta tres de éstos llegan a moverse por la misma escena). Ellos son los que hacen la historia. Son hoscos o encantadores, divertidas, bellas, piadosas, despreocupadas o seductoras.

Büchner elige a uno de estos seres insignificantes, un soldado raso, y construye su realidad para mostrarnos un lado insólito de la historia, una faz que nunca antes tuvo voz, una voz inédita. Y tampoco abundará después, por extraño que parezca. Woyzeck es un ser zarandeado por fuerzas que lo convierten en algo más pequeño todavía, sin otra salida que la tragedia, que se inhala, como en Shakespeare, desde el primer segundo. 
"Jamás has tomado dinero, jamás has contraído deudas, nunca has dormido con una mujer, siempre has llevado una levita decente y nunca has estado borracho. Robespierre, eres de una probidad indignante. A mí me daría vergüenza pasearme treinta años entre el cielo y la tierra, siempre con la misma fisonomía moral, solo por el rastrero placer de hallar a otros peores que a mí”

En La muerte de Danton nos plantea, con una lucidez que causa escalofrío, las relaciones entre violencia y revolución. ¿Hay condiciones en las que es legítima la violencia? Pensemos en una simple manifestación que deriva en carga policial. Una visión a través de «rayos $\mathrm{X}$ » nos mostraría a ciudadanos fuertemente armados frente a otros indefensos. ¿Qué respuesta debe tener una tal carga policial contra ciudadanos y ciudadanas armados con pancartas, voces y pitos? Ambas violencias, aún admitiendo que lo sea la segun$\mathrm{da}$, son inconmensurables. No se pueden comparar. Y no hay violencia «legítima». ¿Es que hemos retrocedido en la historia? $¿$ Alguien se imagina un duelo de honor en el que solo uno de los dos contendientes vaya armado? Es evidente que no habría duelo, pero tampoco honor.

Estas y otras cuestiones, tan de nuestros días, se plantean en la lectura de esta obra. Büchner supo ver los conflictos morales y políticos de los días del terror revolucionario y retrata a Robespierre como si hubiese estado cenando con él la noche anterior. Tal es el grado de extrospección que despliega: "Jamás has tomado dinero, jamás has contraído deudas, nunca has dormido con una mujer, siempre has llevado una levita decente y nunca has estado borracho. Robespierre, eres de una probidad indignante. A mí me daría vergüenza pasearme treinta años entre el cielo y la tierra, siempre con la misma fisonomía moral, solo por el rastrero placer de hallar a otros peores que a mí» (Büchner, 1992:94).

Las sociedades modernas son cada vez más complejas. Las maneras de adocenar y los modos de control son cada vez más sofisticados. En consecuencia, cada vez es más difícil ser libre. Pero la libertad se aparece, más que nunca, como un imperativo moral. Pero ser libres es actuar sin ataduras, no sin contradicciones. Estar vivo es formar parte de procesos cambiantes, movedizos y sutiles, que solo desde la ideología o la violencia se pueden simplificar con éxito.

El joven Büchner, junto a una obra científica interesante y que le permitió ser

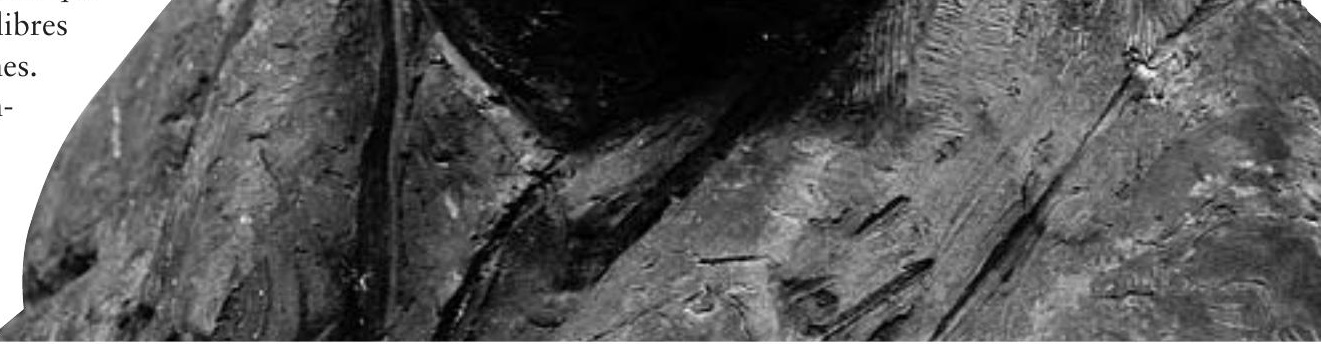


aceptado como docente en la Universidad de Zürich, escribe. Pero también despliega una acción política que tuvo como resultado una acusación de "Alta traición». En la orden de busca y captura dictada contra él podemos ver los rasgos físicos por los que lo habrían de reconocer las autoridades públicas del país y del extranjero, incluida claro está, la policía del Gran Duque Ludovico I:

Talla: 6 pies, 9 pulgadas de la nueva medida de Hesse. Cabello: rubio.

Frente: muy amplia.

Cejas: rubias.

Ojos: grises.

Nariz: fuerte.

Boca: pequeña.

Barba: rubia.

Mentón: redondo.

Rostro: oval.

Color de la tez: saludable.

Figura: fuerte, delgado.

Señas particulares: miopía (Büchner, 1992:271).

Este rasgo final, si bien pudo ser una característica de su ojos, no lo fue, desde luego, de su visión del mundo, todavía hoy tan inquietante para muchos lectores que prefieren el desconocimiento.

Su obra, sin embargo, ha sido valorada en muchos ámbitos. La literatura más exigente en habla alemana ha sido reconocida con un premio que lleva su nombre: Habría que recordar los nombres de Gottfied Benn, Max Frich, Paul Celan, Hans Magnus Enzensberger, Ingeborg Bachmann, Günter Grass, Heinrich Böll, Thomas Bernhard, Elias Canetti, Peter Handke, Elfriede Jelinek o Volker Braun.

Precisamente Paul Celan, al recibir el premio Georg Büchner, escribió el texto «El Meridiano», en el que se pregunta: «¿No existe en Georg Büchner, en el poeta de la criatura, un radical cuestionamiento del arte? (...) ¿Un cuestionamiento al que tiene que volver toda la poesía de hoy, si quiere seguir preguntando?» (Celan, 1999:503).

De Woyzeck se han hecho numerosísimas adaptaciones teatrales, que han resuelto con más o menos fortuna el rompecabezas de los textos originales, que Büchner no dejó finalmente ordenados. Alban Berg compuso su magnífica ópera Wozzeck sobre el mismo texto. Y ha sido llevada también al cine.

No sería justo decir que el legado Büchner no haya sido bien recibido. Lo que queremos decir es que sus textos esperan también a esta generación que ahora empieza a leer. Y que hasta los más indignados ciudadanos de este principio de siglo podrán verse reflejados, si no retratados, en una obra tan breve como precisa. En un texto titulado «La muerte heroica de los cuatrocientos ciudadanos de Pforzheim» dice, refiriéndose a los francos, por ejemplo, algo que puede sonar a los seguidores de Che Guevara, sin ir más lejos: «Prefieren morir de pie a vivir de rodillas» (Büchner, 1992:44).

O en «El mensajero de Hesse» no solo el más co- nocido « $\mathrm{Paz}$ a las chozas! ¡Guerra a los palacios!, que ya era una frase del escritor francés Chamfort (Guerre aux châteaux! Paix aux chaumières!), sino esta otra sentencia demoledora: «Quien dice la verdad muere en la horca» (Büchner, 1992:65).

Büchner dejará escritas muchas páginas en Lenz, en la citada La muerte de Danton o en Leonce y Lena, en las que habla de arte y literatura, pero nos parece que, con frecuencia, los autores al hablar de otros dejan entrever su propia visión del arte. En una simple reseña de un libro sobre el suicidio, el asunto es lo de menos, escribe Büchner unas palabras en las que más bien parece hablar de sí mismo al decir: "que

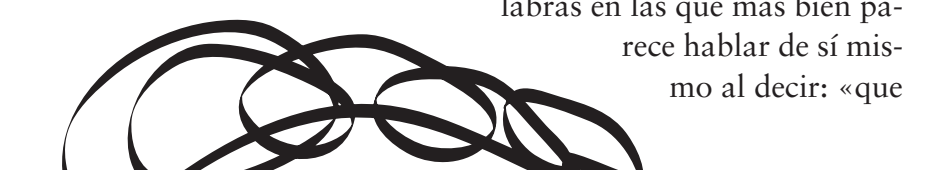


Celebrar los doscientos años del nacimiento de un escritor puede ser un simple motivo para nombrarlo, volver a editar sus obras u organizar actos en su nombre, pero también una excusa para estudiarlo y dar a conocer una literatura que conoció la fórmula alquímica por la que una obra literaria, hecha de tiempo, se transforma en eternidad.

el autor ha evitado la unilateralidad, que observa y enjuicia no desde una perspectiva ajena sino propia e independiente; y que reflexionando sobre el tema ha llegado a adentrarse en el mundo interior y exterior del hombre» (Büchner, 1992:62).

¿Qué autor no aspiraría a que dijeran de sí mismo estas palabras?

Al final de su vida, solía repetir Friedrich Wilhein Murnau, el director de cine, autor de Tabu y Nosferatu, proverbios chinos, en particular el que dice que una imagen vale más que mil palabras. En su caso para afirmar la supremacía de un cine puramente visual frente al efectismo sentimental del sonoro. Pero en Büchner lo que sorprende no son las palabras, sino las potentes imágenes que genera con ellas. Piensa en imágenes, podemos decir. Y las transmite con una precisión infalible. Perdura en nuestra retina y no podemos desprendernos de ellas. No toda la literatura tiene por qué ser así, pero esta es una de las mejores en su género.

Celebrar los doscientos años del nacimiento de un escritor puede ser un simple motivo para nombrarlo, volver a editar sus obras u organizar actos en su nombre, pero también una excusa para estudiarlo y dar a conocer una literatura que conoció la fórmula alquímica por la que una obra literaria, hecha de tiempo, se transforma en eternidad.

\section{Bibliografía}

BÜCHNER, Georg (1992), Obras completas. Madrid: Trotta. (Edición basada en BÜCHNER, G. (1988) Werke und Briefe. Munich. Y en la edición de W. Lehmann, BÜCHNER, G. (1967) Sämtliche Werke und Briefe. Hamburgo.)

CELAN, Paul (1999), Obras completas. Madrid: Trotta.

TOLSTOI, Leon (1956), La guerra y la paz (Voyna i Mir). Traducción directa del ruso: Serge T. Baranov y N. Balmanya. Barcelona, AHR; Guerra y paz, en Obras Completas (2004). Versión directa del ruso: Irene y Laura Adresco. Madrid: Aguilar.

BERRIATÚA, Luciano (1990), Los proverbios Chinos de

F. W. Murnau. Madrid: Filmoteca Española.
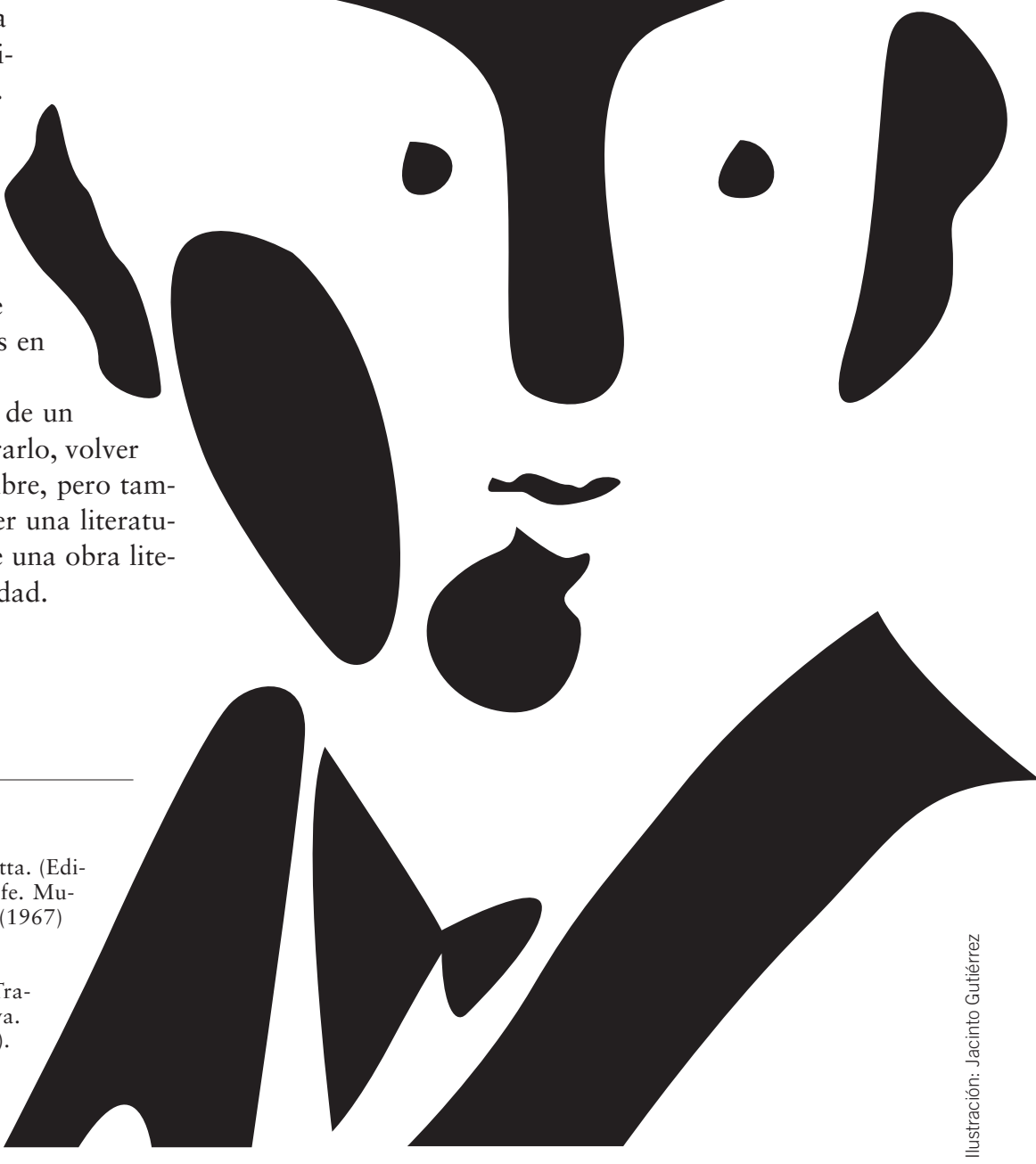